\title{
IMPROVING STUDENT'S VOCABULARY MASTERY THROUGH COOPERATIVE SCRIPT ON DESCRIPTIVE TEXT
}

\author{
Nur Afni Hidayaturrahma ${ }^{1}$, Nenis Siti Aisyah ${ }^{2}$, Rasi Yugafiati $^{3}$ \\ ${ }^{1}$ IKIP SILIWANGI \\ ${ }^{2}$ IKIP SILIWANGI \\ ${ }^{3}$ IKIP SILIWANGI \\ ${ }^{1}$ nurafni.rahma@gmail.com, ${ }^{2}$ nenisyasya@gmail.com, ${ }^{3}$ tanya.rasiyugafiati@gmail.com
}

\begin{abstract}
This study is revealed based on the observation on the tenth grade of X HT 1 Sangkuriang 2 Vocational High School. The subjects of this study were consisted of 31 students. This study was aimed to improve the students' vocabulary mastery using Cooperative Script Method. The research design was Classroom Action Research (CAR) which following from Kemmis and Taggart model. It is used to obtain the results of quantitative and qualitative data using 2 cycles described through planning, action, observation, and reflection on each cycle. The result of the study showed that there was a development on the student's vocabulary mastery. It could be seen from the result of the test. The Minimum Mastery Criteria (KKM) of English lesson was 70. The students mean score in the pre test was 50, in the first post test the mean score was 65 , and in the second post test the mean score was 85 . In addition there were 2 students $(6,4 \%)$ who passed KKM on pre test. In the first pretest there were 9 students $(29,03 \%)$ who passed KKM. In the second pretest there were 29 students $(93,55 \%)$ who passed KKM. Then, from the result of field notes and interview it showed the positive responses from the students. The students can be more active and improve their ideas. The researcher conclude that Cooperative Script method could improve student's vocabulary mastery.
\end{abstract}

Keywords: Vocabulary, Cooperative Script, Descriptive Text, CAR

\section{INTRODUCTION}

Vocabulary is a basic of learning English language. It covers writing, speaking, reading, and listening. Vocabulary is the main key of language. Without vocabulary students difficult to understand the meaning of the text and people utterances. Willis (2008) in (Wilsana, Marhum, \& Kamaruddin (2015) tells when students can increase their mastery of vocabulary, it can be better in communicating ideas, knowledge and their opinions.

In Indonesia, English is the second language which is taught formally from the elementary to the university level. Vocational High School 2 Sangkuriang Cimahi is one of the vocational high school in which the students have problem with their vocabulary. When teacher asked them to say something in English, they do not know how to respond. It is because they are still lack of vocabulary. They are difficult to comprehend the meaning of text. Thus, it can be concluded that vocabulary emerged as the cause of the most difficulty for students. It supported by the previous study entittled "Teaching Vocabulary to Grade VIII Students at SMP 9 Palu by using Word Wall Strategy" by Wilsana, Marhum, kamaruddin (2015) said that many students had difficulties in learning English, especially in the mastery of vocabulary. Based on the statement above, the researcher try to find out the best or the 
effective strategy to make more effective, easier and effortless in teaching English vocabulary.

One of the effective method that can be implemented is Cooperative Script. Cooperative Script is the method that can help the students for developing students' ability in memorizing and achieve the desired learning target. Joliffe (2007) in Pertiwi (2003) states that cooperative learning have shown three main categories of advantages: achievement, interpersonal relationships, and psychological health and social competence. Schank and Abelson in Muliadi (2017) said that Cooperative script method is a learning strategies which describe the students interraction in their real life situation as individual, a member of family, and in environment. On the other hand, Indriani (2018) says that Cooperative Script provides a discussion that helps students to understand the scientific concepts, improve the student's understanding of the concept and eliminate the students misconception. The researcher uses cooperative script method in teaching english with the purpose to help students for mastering vocabulary to understand the text. It is important to implement this method because students can be more active in learning English language as good as when they work by self or team.

The researcher uses descriptive text as the material in teaching vocabulary mastery. In the descriptive text the students can improve their ideas and learn many new words which can be remember by the students. Thus the researcher combines cooperative script method with descriptive text in teaching vocabulary.

Based on the explanation above therefore the researcher conduct the research entitled "Improving students Vocabulary through Cooperative Script on Descriptive text"

\section{METHOD}

The population of this reasearch are the students of SMK Sangkuriang 2 Cimahi. The researcher focuses to the tenth grade X HT 1 which consist of 31 students. The design of this research was Classroom Action Research (CAR). According to Harmer (2007) in Anon (2015), " action research is the name given to a series of procedures teachers can engage, perhaps teacher wish to improve aspect in their teaching or alternatively to evaluate the success of certain activities and procedures". The researcher uses Classroom Action Research by Kemmis and Taggart which consists of : planning, acting, observing, and reflecting.

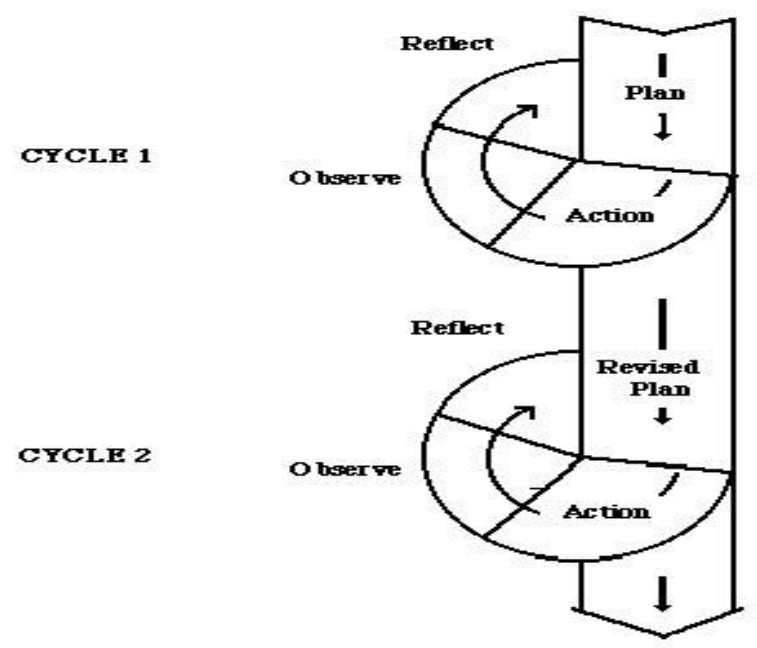

Figure 1. Diagram of Classroom Action Research adapted from Kemmis and Taggart 
The researcher uses two cycles that consist of seven meetings. The first cycle consisted of four meetings, those were : Pre Test, Treatment 1, Treatment 2, and Post Test. The second cycle consists of three meetings, that is : Treatment 3 , Treatment 4 and Post Test.

The technique of collecting data in this research was both qualitative and quantitative data. The researcher uses qualitative data consists of interview and field notes. The interview was to known the difficulties that faced by The students, afterwards field notes was to record activities during teaching learning of vocabulary mastery on descriptive text through Cooperative Script in the classroom. Including description of student's attitude, the teacher's creativity in presenting the material and the classroom's atmosphere. While the quantitative data consist of a test, that is : Pre Test and Post Test. Pre Test before implement the Cooperative Script method and Post Test after implement Cooperative Script method. The test was to measure the ability of student's in improve vocabulary mastery on descriptive text.

\section{RESULTS AND DISCUSSION}

\section{Results}

In cycle 1 , the researcher discover that $29,03 \%$ or 9 from 31 students got the score who passed KKM. It was not given good results in increasing student mastery. Hence, planning in Cycle-1 requires to be repaired so that the next cycle can achieve the success criteria.

The researcher found that the vocabulary mastery student's of the tenth grade X HT 1 was low. The KKM was designed that the students could pass the test if they got score $\geq 70$. It could be showed from the percentage of student's progress in vocabulary test. The result of the test in cycle one and cyle two was different. The percentage of Test in cycle 1 was $29,03 \%$. From the explanation above, the researcher analyzed that there were several problems in the Cycle -1 , that was the post test 1 score has not reach the criteria of success, students still had difficulty focusing on learning English. In cycle two was 93,55 \%, it showed that the teaching learning process was successful after the Cooperative script model used in the class.

Table 1. The table of student's progress in vocabulary test on cycle 1 and cycle 2

\begin{tabular}{cccc}
\hline CYCLE (1 \& 2) & THE AVERAGE & $\begin{array}{c}\text { NUMBER OF } \\
\text { STUDENTS WHO } \\
\text { PASSED KKM }\end{array}$ & PERCENTAGE \% \\
\hline Pretest Cycle 1 & 50 & 2 & $6,4 \%$ \\
\hline Post Test Cycle 1 & 65 & 9 & $29,03 \%$ \\
\hline Post Test Cycle 2 & 85 & 29 & $93,55 \%$
\end{tabular}

From the table 1 above, the researcher concluded that improving student's vocabulary mastery using Cooperative Script in Sangkuriang 2 Vocational high school is success.

\section{Discussion}

The collecting data which was taken from student's observation, interview and test could be said that Cooperative Script method could improve student's vocabulary mastery. The students could active in improve their comprehension and their ideas when they were collaborated with their friends on the group. It was supported by Falchikov (2001) in 
Maulana (2017) said that "Cooperative script can help sudents to understand new material and relate it to previous knowledge, using oral summarizing, metacognitive activities (comprehension, error correcting, evaluation) and elaboration activities".

Thus, the vocabulary mastery was the results obtained by students after learning a descriptive text by cooperative script method in the form of qualitative and quaantitative data.

\section{Cycle 1}

1. Planning

In this step, the researcher made a lesson plan about the material that would be applied in the class. The material is about the name of countries. The writer instructed the student to made descriptive text about the countries.

2. Acting

In this step, the researcher applied what has been planned before. There were the schedule activity that has been done :

Table 2. Schedule activities Cycle 1

\begin{tabular}{ccc}
\hline Meeting & Topic & Activities \\
\hline 1. & Pretest & Give student pre test vocabulary. \\
2. & $\begin{array}{c}\text { Treatment I } \\
\text { (cycle I) }\end{array}$ & $\begin{array}{c}\text { Give students the assignment to analyze a } \\
\text { descriptive text }\end{array}$ \\
\hline 3. & $\begin{array}{c}\text { Treatment II } \\
\text { (cycle I) }\end{array}$ & $\begin{array}{c}\text { Applied the Cooperative script method } \\
\text { through descriptive text. }\end{array}$ \\
\hline 4. & Post test 1 & Give student post test vocabulary.
\end{tabular}

\section{Observing}

The researcher observing the student in learning vocabulary through descriprive text. After that, the reseacher give them post-test worksheet to know their ability in vocabulary.

\section{Reflecting}

The researcher value of the result post-test in the first cycle in the case want to acknowledge post-test/whether it is improved or not, and it turns out that the results obtained were very unsatisfactory. It made the researcher continue on cycle 2 to got good result from this method.

Based on what was found by researcher in cycle 1, the researcher decided to made several revisions to be implemented in Cycle- 2 : a) The researcher give the text for a student, not for a group. Thus, each student got the different text, b) The researcher directly distributes the text to the students, c) The researcher shares the dictionary into the group. Each group gets a dictionary to check the meaning of the selected word.

\section{Cycle 2}

1. Planning

In this step, the researcher made a lesson plan about revised the teaching method that would be applied in the class. The material is about the name of countries. The researcher instructed the student to made descriptive text about the countries. 


\section{Acting}

In this step, the researcher applied what has been planned before. There were the schedule activity that has been done :

Table 3. Schedule activities of Cycle 2

\begin{tabular}{ccc}
\hline 1. & $\begin{array}{c}\text { Treatment I } \\
\text { (cycle II) }\end{array}$ & $\begin{array}{c}\text { Give students the assignment to } \\
\text { analyze a descriptive text } \\
\text { but with billingual language. }\end{array}$ \\
\hline 2. & $\begin{array}{c}\text { Treatment II } \\
\text { (cycle II) }\end{array}$ & $\begin{array}{c}\text { Applied the Cooperative script method } \\
\text { through descriptive text using bilingual } \\
\text { language }\end{array}$ \\
\hline 3. & Post test & Give student post test vocabulary \\
\hline
\end{tabular}

\section{Observation}

In this step the researcher collect data about the vocabulary obtained by students after conducting Cooperative Script, and analyze the influence of student attitudes in the class.

\section{Reflection}

If the result was reach the KKM, it was not necessary to continue to the next cycle. Fortunately on this second cycle the researcher has got the expected result.

From the statement above, the researcher analyzed that almost the problems in the Cycle -1 could be corrected in the Cycle- 2. Most of the students' scores in the Post-Test 2 could reach the criteria. The students involved themselves in learning English, especially in vocabulary mastery. The students received the materials in which the teacher used on that days. On the basis of the good results in the Post-Test 2, the researcher did not need to continue the research. From the discussion above, the researcher concluded that using Cooperative Script to improve student's vocabulary mastery in Sangkuriang 2 Vocational high school was successed.

\section{CONCLUSION}

Based on the result, the researcher conclude that the implementation of Cooperatif Script method could improve student's vocabulary mastery on the tenth grade Vocational High School. It could be proved from the several facts. First, the improvement could be seen from the percentage of students who passed Minimum Mastery Criterion - Kriteria Ketuntasan Minimal (KKM). In the first cycle the percentage of students score got $29,03 \%$, and in the second cycle the percentage of students score 93,55\%. Second, from the result of field notes the researcher found that the atmosphere of class was different when the students use bilingual language, the students could be more active and improve their ideas. Third, from the result of interview the researcher gave positive responses, the Cooperative Script method made the students interest to be more active in the class. Moreover, Cooperative Script method would be alternative strategy in improve students vocabulary mastery. 


\section{ACKNOWLEDGMENT}

\section{In the name of Allah,The Beneficent, The Merciful}

Praise be to Allah, Cherisher and Sustainer of the world. Who has given the researcher a chance to learn, strength and guidance for the researcher, therefore this journal can be finished. Peace and blessing be upon to prophet Muhammad SAW, his families, his relatives and all followers.

This journal is written to fulfill the requirement of the final exam on Sarjana Degree at the English Departement IKIP Siliwangi Bandung. The researcher would like to express great appreciation and thanks to all lectures in English Education Study Program, especially to Miss Rasi Yugafiati, M.Pd to guide, advise, and motivate the researcher until finish the project. The reseracher also like to show the gratitude to parents, and friends who support the researcher. The researcher realizes this journal far from perfect, but the researcher hope this research can be useful and be reference for the reader or the other researcher in the future.

\section{REFERENCES}

Anon. (2015). Chapter III. 1999, 26-36. https://doi.org/10.1111/j.1755-3768.1980.tb00580.x Indriani, D. E. (2018). Cooperative Scripts Model in Civic Education for Elementary School Students. Humaniora, 8(2), 105. https://doi.org/10.21512/humaniora.v8i2.3888

Muliadi. (2017). Cooperative Script Learning Model to Improving Student Listening Skills. IOSR Journal of Research \& Method in Education (IOSRJRME), 07(03), 98-107. https://doi.org/10.9790/7388-07030498107

Pertiwi, A. D. (2003). The Implementation Of Cooperative Script Technique In Teaching Reading Comprehension To The Students Of Senior High School. 87-98.

Wilsana, A., Marhum, M., \& Kamaruddin, A. (2015). Teaching Vocabulary To Grade Viii Students At Smp Negeri 9 Palu By Using Word Wall Strategy. E-Jurnal Bahasantodea, $3,23-35$. 